\title{
PENDIDIKAN POLITIK BERBASIS DESA ADAT BAGI KAUM PEREMPUAN DI DESA TIGAWASA KECAMATAN BANJAR KABUPATEN BULELENG
}

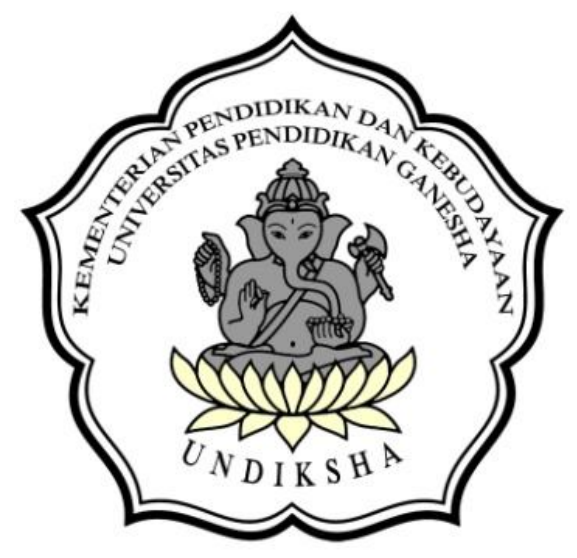

ARTIKEL

Oleh

Ni Ketut Restini

NIM 1014041068

JURUSAN PENDIDIKAN PANCASILA DAN KEWARGANEGARAAN

FAKULTAS ILMU SOSIAL

UNIVERSITAS PENDIDIKAN GANESHA

SINGARAJA

2014 


\title{
PENDIDIKAN POLITIK BERBASIS DESA ADAT BAGI KAUM PEREMPUAN DI DESA TIGAWASA KECAMATAN BANJAR KABUPATEN BULELENG
}

\author{
Ni Ketut Restini, Drs.I Wayan Landrawan,M.Si, \\ Ni Ketut Sari Adnyani,S.Pd,.M.Hum \\ Jurusan Pendidikan Pancasila dan Kewarganegaraan, Fakultas IImu Sosial, \\ Universitas Pendidikan Ganesha Singaraja, Indonesia \\ e-mail: tini res@yahoo.com,landra one@yahoo.co.id, \\ sariadnyani@yahoo.co.id
}

\begin{abstract}
ABSTRAK
Penelitian ini bertujuan untuk mengetahui ; (1) Bagaimana proses pendidikan politik bagi kaum perempuan di desa Tigawasa ; (2) Untuk mengetahui bagaimana partisipasi perempuan dalam kehidupan politik di desa Tigawasa sebelum dan sesudah diterapkan pendidikan politik ; (3) Untuk mengkaji bagaimana keberterimaan laki-laki terhadap partisipasi perempuan dalam kehidupan politik di desa Tigawasa.

Penelitian ini menggunakan rancangan penelitian deskriptif kualitatif. Lokasi penelitian ini adalah di desa Tigawasa Kecamatan Banjar, Kabupaten Buleleng. Subyek penelitian ini adalah; Kepala desa dan stafnya, Prajuru desa adat, anggota masyarakat, kaum perempuan di desa Tigawasa. Data penelitian ini dikumpulkan dengan menggunakan teknik observasi, teknik wawancara, dan teknik pencatatan dokumen.

Hasil penelitian menunjukan bahwa; (1) Bahwa proses pendidikan politik di desa Tigawasa relatif sudah berjalan dengan sangat baik. Proses pendidikan politik ini, berjalan melalui proses pendidikan formal yang diakui oleh masyarakat, khususnya para perempuan di desa Tigawasa. Kesadaran para orang tua untuk menyekolahkan anak-anaknya, termasuk anak perempuan sudah relatif tinggi. Hal ini ditunjukan dengan terus meningkatnya tingkat pendidikan politik di masyarakat, proses pendidikan perempuan di desa Tigawasa di awali dari pendidikan di sekolah, keluarga, masyarakat dan di desa adat. (2) Bahwa partisipasi perempuan di desa Tigawasa sebelum adanya pendidikan politik relatif rendah, yaitu partisipasinya dalam kehidupan politik berkisar 30\%. Setelah melalui pendidkan politik baik lewat pendidikan formal maupun informal, partisipasi perempuan di Tigawasa dalam kehidupan politik meningkat menjadi $75 \%$. (3) Kaum laki-laki di desa Tigawasa sudah mengakui hak-hak kaum perempuan dalam partisipasinya di kegiatan politik seperti memberikan suara dalam pemilihan umum, menjadi anggota suatu partai politik atau kelompok kepentingan, mengadakan hubungan (contracting) dengan pejabat pemerintah atau anggota parlemen, dan mendukung bila nantinya akan ada perempuan yang menjadi pemimpin yang bisa membawa desa Tigawasa kearah yang lebih maju.
\end{abstract}

Kata Kunci : Pendidikan politik, desa adat, kaum perempuan. 


\title{
CUSTOMARY VILLAGE BASED POLITICAL EDUCATION FOR WOMEN IN TIGAWASA VILLAGE OF BANJAR DISTRICT OF BULELENG REGENCY
}

\author{
Ni Ketut Restini, Drs.I Wayan Landrawan,M.Si, \\ Ni Ketut Sari Adnyani,S.Pd,.M.Hum \\ Jurusan Pendidikan Pancasila dan Kewarganegaraan, Fakultas IImu Sosial, \\ Universitas Pendidikan Ganesha Singaraja, Indonesia \\ e-mail: tini res@yahoo.com,landra one@yahoo.co.id, \\ sariadnyani@yahoo.co.id
}

\begin{abstract}
This study was mainly aimed at (1) finding out political education process for women in Tigawasa village (3) investigating men's acceptance of women's participation in political life in Tigawasa village. This research uses descriptive qualitative research design. The location of this research is in the village of Tigawasa Banjar subdistrict, Buleleng regency. The subjects of this study were; The village chief and his staff, Devices traditional village, community members, women in the village Tigawasa. The data was collected by using observation, interview techniques, and documents recording techniques. The results showed that; (1) That the process of political education in the village relative Tigawasa already well underway. The political education process, walk through the process of formal education that is recognized by the society, especially women in rural Tigawasa. Awareness of parents to educate their children, including girls already high relatife. This is evidenced by the increasing level of political education in society, the education of women in rural Tigawasa at the start of education in schools, families, communities and in the traditional village. (2) That the participation of women in the village Tigawasa before the political education is relatively low, ie participation in political life ranging from $30 \%$. After going through political education both through formal and informal education, women's participation in political life Tigawasa increased to $75 \%$. (3) the men in Tigawasa village have recognized women's rights in political activities such as voting in elecation, becoming a member of a political party or an interest group, contracting a government official, or aparliament member and support them when in the future a woman will become a leader who will bing Tigawasa toward a better condition
\end{abstract}

Keywords: Political education, customary village, women. 


\section{PENDAHULUAN}

Hal ini sangat penting, mengingat telah berlakunya Undang-Undang Republik Indonesia No. 2 Tahun 2008 Tentang Partai Politik, dimana dalam pasal 2 ayat (2) menyebutkan " Pendirian dan pembentukan Partai Politik sebagai mana dimaksud pada ayat (1) menyertakan 30\% (tiga puluh perseratus) keterwakilan perempuan". Oleh karena itu peran aparat desa dalam memberikan pendidikan politik pada kaum perempuan sangat diperlukan agar mampu melahirkan partisipan politik dari kaum perempuan.

Terbentuknya gerbang reformasi 1998 diakui telah memberikan kontribusi terjadinya perubahan-perubahan tatanan kehidupan sosial politik di Indonesia. Adanya amademen undang-undang ( UU ), khususnya revisi UU Kepartaian, telah menghasilkan Undang-Undang Republik Indonesia No. 31 Tahun 2002 tentang partai politik, dimana Undang-Undang ini telah memberikan kesempatan luas bagi warga Negara untuk mendirikan partai politik. Revisi Undang-Undang (UU) tersebut telah mendorong masing-masing kelompok untuk mendeklarasikan partai politik, baik yang berasal dari kalangan nasionalis maupun akademis.

Seiring dengan perkembangan zaman tingkat modernisasi dan globalisasi informasi serta keberhasilan gerakan emansipasi perempuan dan feminisme, sikap dan peran perempuan khususnya, pandangan tentang dunia politik mulai mengalami pergeseran. Peremuan tidak lagi berperan ibu rumah tangga yang menjalankan fungsi produksi, mengasuh anak dan suami atau pekerjaan domestik lainnya, tetapi sudah aktif berperan diberbagai dibidang pendidikan, baik social, ekonomi maupun politik. Bahkan pekerjaan tertentu yang sepenuhnya atau dua puluh tahun lalu hanya pantas dilakukan oleh lakilaki, saat ini pekerjaan tersebut sudah biasa dilakukan oleh para perempuan, termasuk pekerjaan kasar sekalipun.

Walaupun perempuan sudah terlibat ke sektor-sektor publik, namun jumlahnya masih relatif kecil. Hal ini sangat kontras dengan prosentase jumlah penduduk perempuan di Indonesia. Diantara sektorsektor publik yang telah dimasuki perempuan, sektor politik merupakan hal yang sangat menarik sekalipun sangat penting. Menarik karena secara historis memang sangat sedikit telihat keterlibatan perempuan dalam sektor ini, sangat penting karena sesungguhnya keterlibatan perempuan dalam sektor politik dapat berpengaruh sangat besar pada kebijakan yang diambil, khususnya dalam kaitannya dengan peran perempuan secara menyeluruh. Hal ini dapat terjadi karena suara-suara perempuan akan lebih nyaring didengar disuarakan oleh, misalnya anggota parlemen. Bila lebih banyak perempuan yang duduk dibadan legislatif, maka akan dapat diharapkan adanya suara yang nyaring itu.

Seiring dengan kondisi di atas, peningkatan pendidikan politik perlu dilakukan untuk meningkatkan sikap politik masyarakat. Salah satu alternatifnya adalah dengan memfungsikan berbagai lembagalembaga sosial kemasyarakatan yang telah ada, khususnya bagi kaum perempuan. Disamping itu, gerakan emansipasi wanita menurut kesejajaran dan keutamaan berbagai bidang profesi dengan kaum lakilaki. Hal ini berarti, adanya upaya-upaya terpogram dari kaum perempuan untuk memperoleh pengakuan dan tempat yang sama dengan kaum laki-laki dalam berbagai system kehidupan dimasyarakat.

Dengan munculnya kebijakan pemerintahan yang tertuang dalam pasal 61 ayat 1 Undang-Undang No 12 Tahun 2003 tentang pemilu yang mengenai kuota 30 persen bagi perempuan merupakan respon atas berbagai persoalan yang melilit kaum perempuan Tigawasa. Sekaligus sebagai upaya mengakomondasi kepentingan dan hak-hak kaum perempuan, terutama di dalam wilayah politik. Sejarah telah mencatat perjuangan perempuan Tigawasa dalam memperjuangkan hak-haknya agar setara (equality) dengan kaum laki-laki (maskulin).

Studi kausalitas politik educational menunjukan beberapa kelemahan baik dari proses maupun hasilnya, antara lain dalam aspek metode dan media pendididkan politik itu sendiri. Dimana pola indoktrinasi dan provokasi lebih medominasi proses pendididkan politik selama ini kalangan masyarakat. Hal ini berdampak pada 
lemahnya pemahaman dan wawasan masyarakat tentang politik, yang pada akhirnya berdampak pada rendahnya kapabilitas politik masyarakat secara umum. Dimana kita ketahui adanya kecendrungan dikalangan masyarakat, khususnya kaum perempuan, bahwa politik merupakan suatu yang kotor dan menjijikan, bahkan lebih dari sesuatu yang itu "haram" untuk dilakoni, khususnya bagi kaum perempuan di daerah pedesaan. Hal ini diduga bersumber pada lemahnya proses pendidikan dan sosialisasi politik itu sendiri, karena pola pendidikan politik yang dikembangkan selama ini lebih banyak diwarnai oleh muatan-muatan politik penguasa sehingga masyarakat tidak memiliki kesempatan untuk mengekspresikan aspirasi dan sikap politiknya secara optimal. Artinya, pola pendidikan seperti itu, tidak menjadikan masyarakat paham dan mampu belajar apa itu politik, melainkan justru menjadikan masyarakat lebih bodoh, skeptik dan apriori terhadap politik. Hal ini yang harus diperhatikan oleh aparat desa untuk dapat memberikan pendidikan politik supaya masyarakatnya khususnya kaum perempuan mempunyai pemahaman dan wawasan tentang politik.

Hal ini sangat penting, mengingat telah berlakunya Undang-Undang Republik Indonesia No.2 Tahun 2008 Tentang Partai Politik, dimana dalam pasal 2ayat (2) menyebutkan"Pendirian dan pembentukan Partai Politik sebagai mana dimaksud pada ayat (1) menyertakan $30 \%$ (tiga puluh perseratus) keterwakilan perempuan". Oleh karena itu peran aparat desa dalam memberikan pendidikan politik pada kaum perempuan sangat diperlukan agar mampu melahirkan partisipan politik dari kaum perempuan.

Pendidikan politik merupakan bagian dari sosialisasi politik. Pendidikan politik mengajarkan masyarakat untuk lebih mengenal sistem politik negaranya. Dapat dikatakan bahwa sosialisasi politik adalah proses pembentukan sikap dan orientasi politik para anggota masyarakat. Melalui proses sosialisasi politik inilah para anggota masyarakat memperoleh sikap dan orientasi terhadap kehidupan politik yang berlangsung dalam masyarakat.
Bahwa pendidikan politik adalah suatu bentuk pendidikan yang dijalankan secara terencana dan disengaja baik dalam bentuk formal maupun informal yang mencoha untuk mengajarkan kepada setiap individu agar sikap dan perbuatannya dapat sesuai dengan aturan-aturan yang berlaku secara sosial. Dalam hal ini dapat terlihat bahwa pendidikan politik tidak hanya mempelajari sikap dan tingkah laku individu. Namun pendidikan politik mencoba untuk mengaitkan sikap dan tingkah laku individu tersebut dengan stabilitas dan eksistensi sistem politik.

Masayarakat pedesaan sebagai salah satu komunitas sosial yang ada dan berkembang dengan dinamika jaman, tidak terlepas dari pengaruh dan tuntutan pembaharuan menuju masayarakat yang mandiri dan mampu bersaing di tengahtengah gelombang globalisasi. Gerakan pembangunan yang sudah, sedang dan akan dilaksanakan telah banyak berorientasi dan memberi prioritas pada pembangunan masyarakat pedesaan. Hal ini dipertegas lagi dengan wancana masyarakat madani (Civil Society) yang secara nasional sedang digalakan saat ini. Upaya pembangunan masyarakat menuju terwujudnya masyarakat madani telah dilakukan secara terprogram dan terencana melalui penataan berbagai sistem dan aspek kehidupan masyarakat. Salah satu aspek kehidupan masyarakat yang saat ini banyak disorot oleh berbagai kalangan adalah aspek politik dan ekonomi. Kedua aspek ini begitu popular setelah bangsa ini memasuki era reformasi total sejak tahun 1998. Untuk mewujudkan suatu kehidupan politik yang sesuai dengan tuntutan reformasi perlu ditumbuh kembangkan pendidikan politik bagi seluruh lapisan masyarakat. Hal ini ada kaitannya dengan presepsi yang negatif masayarakat terhadap politik, yang tumbuh dan berkembang di kalangan masyarakat pedesaan.

Kaji petik Nasarudin (1990: 32) yang menemukan adanya kecendrungan dikalangan masyarakat, khususnya kaum wanita bahwa politik merupakan sesuatu yang kotor dan menjijikan, bahkan lebih dari sesuatu yang "haram". Hal ini diduga 
bersumber pada lemahnya proses pendidikan politik itu sendiri, karena pola pendidikan politik yang dikembangkan lebih banyak diwarnai oleh muatan-muatan politis penguasa sehingga masyarakat tidak memiliki kesempatan untuk mengekspresikan aspirasi politiknya. Artinya pola pendidikan seperti itu, melainkan justru menjadikan masyarakat

Dewasa ini, kesempatan masyarakat bagi wanita dalam kehidupan sosial ekonomi dan aspek kehidupan lainnya makin terbuka. Hal ini dapat dilihat dari segi banyaknya wanita yang dewasa ini tidak hanya mempunyai satu pilihan (menjadi istri atau menjadi ibu) tetapi mempunyai banyak pilihan; menjadi istri dan ibu atau bekerja dengan menunda atau bahkan tidak melakukan perkawinan, atau pilih kerja sambil membina keluarga dan sebagainya. Meskipun sebagian besar wanita masih bekerja karena mereka tidak mempunyai pilihan lain, tetapi dewasa ini telah mulai banyak juga wanita Indonesia yang bekerja tidak karena keharusan ekonomi keluarganya. Berbagai peran adalah cara yang paling efektif juga sangat strategis dalam memperjuangkan keterwakilan wanita dalam politik formal. Ini harus berkaitan dengan jelas mengenai peran apa yang dapat dimainkan dan tugas harus dikerjakan oleh organisasi masyarakat, organisasi wanita, kalangan akademik, khusus wanita dalam partai politik dan kelompok swasta atau organisasi professional yang mendukung caleg perempuan. Pemikiran ketika beberapa kelompok mendukung perjuangan kuota perempuan adalah adanya ide untuk membuat perempuan-perempuan ini menjadi agen perubahan sosial dan politik menuju masyarakat lebih bodoh dan apreori terhadap politik (perempuan pedesaan).

Peranan politik dikalangan kaum perempuan sebagiman diuraikan diatas, tampak yang menjadi keresahan adalah rendahnya pemahaman dan wawasan politik masyarakat, khususnya kaum wanita. Di lain pihak makin dirasakan tantangan yang kuat untuk meningkatkan kesadaran politik masyarakat sebagai perwujudan tanggung jawab pemerintah dalam bidang pembangunan. Untuk itu diperlukan suatu studi mendalam guna untuk mencari alternative bagi peningkatan kesadaran politik masyarakat khususnya kaum perempuan.

Perempuan adalah makhluk yang unik karena di balik kelemaha-lembutannya sering wanita dicap mahluk yang lemah atau pun sebutan lain, tetapi terkadang perempuan lebih kuat dari seorang laki-laki yang menjadi pelindung ketika masa berumah tangga diman pada saat berumah tangga peranan perempuan menjadi ganda, disamping mengurus rumah tangga, berperan didesa adat seperti ayah-ayaha desa, melahirkan, perempuan juga bekerja membantu suami untuk memenuhi kebutuhan rumah tangganya dari kenyataan ini dapatlah kita lihat betapa pentingnya peranan perempuan dalam kehidupupan rumah tangga akan tetapi sosok perempuan jaman sekarang sudah mulai mengalami perubahan, perempuan tidak lagi hanya sebagai ibu rukah tangga atau membantu suami berkerja diladang atau disawah, akan tetapi perempuan sekarang sudah mulai mengalami kemajuan yang sangat pesat, dimana perempuan sekarang sudah menjadi perempuan karier yang bekerja dikantoran meski sebagai pegawai biasa. Perempuan Bali umumnya juga sulit mengubah hal-hal yang sudah diyakini sejak lama. Seiring dengan perkembangan teknologi, wanita Bali juga harus siap berubah. Sudah saatnya perempuan Bali bersama-sama melakukan pelestarian budaya secara utuh ,namun dinamis, sesuai dengan perkembangan jaman. Perempuan Tigawasa harus pintar-pintar membagi waktu, perempuan tidak saja menjadi ibu rumah tangga saja tetapi terbuka untuk peran lainnya yang tak terbatas. Dibalik itu semua perempuan bali harus kembali kedapur dalam arti luas, dapur untuk menyiapakan makanan bagi keluarga dan juga yang utama menyiapakan yadnya (korban suci) sehari-hari. Disamping itu tetap berperan aktif dalam kegiatan adat yang lain di lingkungan sosialnya, dalam hal ini di lingkungan sekitar yang dikenal dengan mebanjaran atau menyamebraya (kehidupan berbanjar).

Kedudukan perempuan sangat terhormat. Perempuan merupakan benteng terakhir moralitas. Apabila moralitas 
perempuan merosot maka moralitas masyarakat secara keseluruhan juga merosot. Memberi alas an atas wawasan ini, apa bila hal-hal yang bertentangan dengan dharma merajarela dalam keluarga, kaum perempuan dalam keluarga ternoda dan dengan merosotnya kaum perempuan, lahirlah keturunan yang tidak diinginkan. Tak dapat dipungkiri bahwa perempuan Bali penuh pengabdian meneruskan keturunan, merawat anak, melayani suami, bekerja, melayani budaya adat istiadat, agama dan leluhur. Kelestarian budaya Bali juga berkat peran serta dari wanita Bali.

Masalah perempuan di desa Tigawasa, terutama yang menyangkut peran politiknya, merupakan salah satu aspek yang menarik untuk dikaji secara ilmiah pada pemilu tahun 2014, beberapa partai politik di Kabupaten Buleleng telah membuka kesempatan yang sama kepada kaum perempuan untuk berpartisipasi dalam politik (pemilu), dalam realitasnya wanita Tigawasa kurang menggunakan kesempatan tersebut, sehingga lebih banyak digunakan oleh kaum laki-laki. Masalah ini menarik tidak hanya karena kehidupan wanita di Desa Tigawasa memiliki karakteristik yang unik sebagai masyarakat Bali Aga, tetapi juga dalam kaitannya dengan upaya peningkatan kualitas peran wanita pada umumnya dalam kehidupan sosial, budaya, agama, politik dan ekonomi.

Arga (dalam Noviari, 2010:8) menyatakan bahwa perempuan dalam tataran budaya masyarakat Tigawasa memiliki posisi yang cendrung terbaikan dalam system pemerintaha desa, sehingga aktivitas sosial politiknya sering menjadi objek pelengkap dan hiasan pernik-pernik budaya setempat. Demikian juga halnya dengan studi pendahuluan terhadap tokohtokoh desa adat dan desa administrasi menunjukan bahwa partisipasi politik kaum perempuan Tigawasa dalam pemerintahan desa adat dan desa administrasi terasa sangat kurang. Ini ditunjukan walaupun paruman sekha truna-truni ternyata peran kelompok truni sangat kurang dalam pengambilan keputusan paruman dan terjadi dikriminisasi yang tegas dalam pembagian tugas kerja. Keadaan seperti ini mengesahkan adanya marginalisasi peran kaum perempuan dalam perpolitikan.

Gambaran diatas menunjukan ketidak seimbangan peranan perempuan di dalam bidang politik sangatlah unik untuk di pelajari dan dijadikan bahan penelitian ilmiah. Oleh kerenanya penulis sangat tertarik untuk meneliti keadaan tersebut dan dijadikan bahan pebuatan skripsi dengan judul "Pendidikan Politik Berbasis Desa Adat bagi kaum perempuan di desa Tigawasa Kecamatan Banjar Kabupaten Buleleng ".

\section{METODE PENELITIAN}

Jenis Penelitian deskriptif kualitatif merupakan Prosedur penelitian berdasarkan data deskriptif, yaitu berupa lisan atau kata tertulis dari seseorang subyek yang telah diamati dan memiliki karakteristik bahwa data yang diberikan merupakan data asli yang tidak diubah serta menggunakan cara yang sistematis dan dapat dipertanggungjawabkan kebenarannya. Melalui pendekatan ini, peneliti akan mencoba untuk mendeskripsikan secara kualitatif pendidkan politik berbasis desa adat bagi kaum perempuan di desa Tigawasa, Kecamatan Banjar, Kabupaten Buleleng, semua data yang diperoleh, nantinya akan diuraikan secara sistematis dan aktual dalam kata-kata secara deskripsi.

Lokasi penelitian ini dilakukan oleh di desa Tigawasa, Kecamatan Banjar, Kabupaten Buleleng. Alasan desa Tigawasa tersebut sebagai lokasi penelitian karena didasarkan pada suatu kenyataan bahwa kaum permpuan di desa Tigawasa, terkait dengan sikap politik, masih belum maksimal, berdasarkan pengamatan awal, bahwa desa Tigawasa ini mengembangkan pelaksanaan pendidkan politik berbasis desa adat bagi kaum perempuan di desa Tigawasa, Kecamatan Banjar, Kabupaten Buleleng tetap eksis berlaku sesuai awigawig yang berlaku di desa Tigawasa.

Informan Penelitian Dalam penelitian ini yang menjadi subyek penelitian terdiri dari beberapa pihak yang berdasarkan pertimbangan memiliki nilai kualitas dan ketetapan untuk berperan proaktif sebagai subyek penelitian sesuai dengan tuntutan karakteristik masalah penelitian. Subyek 
penelitian adalah pendukung dari apa yang akn diteliti si peneliti (Netra, 1974 : 22). Adapun pendukung (subyek) dalam suatu penelitian dapat berupa manusia, tanah, tumbuhan, hewan, ataupun benda. Oleh karena itu dapat ditarik kesimpulan bahwa subyek penelitian tersebut merupakan pendukung bagi peneliti dalam melakukan suatu penelitian. Penentuan subyek dalam penelitian ini menggunakan teknik pengumpulan data observasi, wawancara, pencatatan dokumen. Teknik analisis data deskriptif kualitatif.

Berdasarkan hal tersebut maka yang menjadi subjek penelitian adalah : (1) Kepala desa dan setafnya, (2) Prajuru desa adat, (3) Tokoh-tokoh perempuan di desa Tigawasa, (4) Ibu-lbu PKK, (5) Kelompok truna-truni desa adat Tigawasa.

Teknik Pengumpulan Data Pengumpulan data merupakan segolongan metode yang khusus digunakan sebagai alat untuk mencari data dalam suatu penelitian (Netra,1974: 40). Berdasakan hal tersebut, selama berlangsungnya pengumpulan data, maka peneliti menggunakan bebeapa teknik dalam pengumpulan data, antara lain : teknik observasi,wawancara, pencatatan dokumen

Teknik pengolahan data yang digunakan adalah teknik analisis data deskriftif kualitatif yaitu suatu cara dalam pencarian fakta, suatu kondisi, suatu sistem pemikiran atau suatu peristiwa pada masa sekarang dan data yang diperoleh disusun serta dikelompokan kedalam kategorikategori dengan mengacu kepada pokok bahasan yang telah ditetapkan, selanjutnya dilakukan analisis untuk mengecek kesesuaian data dari berbagai sumber atau alat pengumpulan data yang digunakan.

\section{HASIL PENELITIAN DAN PEMBAHASAN \\ 3.1 Hasil Penelitian \\ 3.1.1 Proses Pendidikan Politik Bagi Kaum Perempuan Tigawasa}

Pada umumnya sebagian besar masyarakat di desa Tigawasa bermata pencarian sebagai petani dan kerajinan seperti membuat bedeg, sokasi dan anyamanyaman dan yang lainnya, oleh karenanya kesadaran untuk menyekolahkan anakanak mereka kejenjang yang lebih tinggi sangatlah kurang. Hal inilah yang menyebabkan tingkat pendidikan di daerah ini sangat rendah, hanya sebagian warga yang mempunyai kesadaran untuk bisa memperoleh pendidikan yang sudah diprogramkan oleh pemerintah. Hanya sebagian warganya yang dapat merasakan pendidikan hingga ketingkat perguruan tinggi atau sederajat. Namun seiring dengan tuntutan zaman maka secara perlahan-lahan masyarakat telah sadar akan arti penting dari pendidikan itu sendiri yang dibuktikan dengan terus meningkatnya potensi pendidikan di desa ini. Hal ini tidak terlepas dari kesadaran dari keluarga-keluarga yang menginginkan anaknya lebih maju untuk bekal kehidupannya.

Sebagaimana secara umum keluarga adalah lingkungan pertama dan utama bagi itu pembentukan kepribadian dan pendididkan sosial serta keterampilan untuk bekal hidup,maka proses pendidikan politik tentunya menjadi bagian dalam setiap usaha pendidikan dalam keluarga tersebut. Bagi masyarakat desa Tigawasa keberadaan desa adat tidaklah terlepas dari lingkungan keluarga, karena mereka yang menjadi anggota desa adat adalah mereka yang sudah berumah tangga. Dengan demikian pendidikan politik tentu juga menjadi bagian yang tidak bisa terlepas dari pendidikan keluarga pada masyarakat desa adat Tigawasa.

Meskipun pendidikan politik itu tidak diakui secara tertulis dan tidak dilakukan secara berencana dan sistematis, namun hal ini dapat diketahui dari mekanisme dan pola pendidikan demokrasi dalam keluarga dimana setiap anggota keluarga mengetahui dan menghormati struktur dan kedudukan masing-masing anggota keluarga. Kebanyakan keluarga yang ada di desa tigawasa memang diakui bahwasanya kedudukan suami lebih tinggi atau sebagai kepala keluarga. Ini merupakan konsekwensi dari diterapkannya budaya kekerabatan yang bersifat patriarki. Namun demikian, dilihat secara politik sesunggunya proses pendidikan yang berlangsung dalam lingkungan keluarga di desa ini bersifat demokratis, dalam arti bahwa sesungguhnya suami maupun istri memiliki kedudukan yang sama dalam memutuskan 
segala sesuatu yang menyangkut masalah keluarganya sendiri. Manakala ini terkait dengan kepentingan desa adat dan hanya kaum laki-laki yang dapat mewakili keluarganya.

Sebagaimana secara umum keluarga adalah lingkungan pertama dan utama bagi itu pembentukan kepribadian dan pendididkan sosial serta keterampilan untuk bekal hidup, maka proses pendidikan politik tentunya menjadi bagian dalam setiap usaha pendidikan dalam keluarga tersebut. Bagi masyarakat desa Tigawasa keberadaan desa adat tidaklah terlepas dari lingkungan keluarga, karena mereka yang menjadi anggota desa adat adalah mereka yang sudah berumah tangga. Dengan demikian pendidikan politik tentu juga menjadi bagian yang tidak bisa terlepas dari pendidikan keluarga pada masyarakat desa adat Tigawasa.

\subsubsection{Proses Pendidikan Politik Perempuan Tigawasa Di Dalam Desa Adat}

Membahas tentang desa, mungkin ada baiknya terlebih dahulu menjelaskan pengertian "Desa" yang ada di bali. Desa dalam pengertian hukum nasional, sesuai dengan batasan yang tersirat dan tersurat dalam undang-undang No 5 tahun 1979 tentang pemerintahan desa yang menyebutkan bahwa desa adalah suatu wilayah yang ditempati oleh sejumlah penduduk sebagai kesatuan masyarakat hukum yang mempunyai organisasi pemerintahan terendah langsung dibawah camat dan berhak menyelenggarakan rumah tangganya sendiri dalam ikatan negara Kesatuan Republik Indonesia (pasal $1(\mathrm{a})$ ).

Desa dalam pengertian Adat, yaitu mengacu pada kelompok tradisional dengan dasar ikatan adat-istiadat, oleh adanya tiga pura utama disebut dengan Kahyangan Tiga atau pura lain yang berfungsi seperti itu, yang disebut dengan Kahyangan Desa. Desa Adat merupakan suatu komunitas tradisional dengan fokus fungsi dalam bidang adat dan agama Hindu dan merupakan suatu kesatuan wilayah dimana para anggotanya secara bersamasama melaksanakan kegiatan sosial dan keagamaan yang ditata oleh suatu sistem budaya. Desa Adat merupakan persekutuan masyarakat hukum secara tradisional yang telah tumbuh dan berkembang di Bali sejak ratusan tahun lalu. Dalam hal ini berbicara mengenai lingkungan pendidikan politik di Desa Tigawasa khususnya bagi wanita sesungguhnya tidak hanya terlepas pada lingkungan kelurarga. Pada lingkungan desa adat pun sesungguhnya dapat terjadi dan merupakan wahana pendidikan politik bagi kaum wanita. Hal ini tentunya dikarenakan dengan seiring adanya sebagai sebuah republik di dalam desa adat.

Biasanya tugas dari kerama desa khususnya kaum wanita adalah mejejaitan atau menyiapkan jajan untuk upacara selebihnya adalah menjadi tugas bagi kaum laki-laki seperti menyiapkan daging sesajen, menyiapkan perlengkapan dan runtutan upacara, memimpin atau memuput upacara, mengadakan dan memimpin rapat, memutuskan, merencanakan dan sebagainya. Maka jelaslah dapat dilihat bahwa tugas, peran kekuasaan, wewenang dan kewajiban kerama desa laki-laki lebih besar dari kaum wanita. Namun ada pula kewajiban-kewajiban tentu yang hanya diberikan sebagai penghormatan bagi kaum wanita seperti : tugas tukang luh untuk menyiapakan perlengkapan upacara di pura, dan mengaturkan tari rejang, meskipun peranan wanita tidak berhak mengambil keputusan namun mereka tetap memiliki hak dalam kelangsungan proses upacara. Tanpa adanya partisifasi dari kaum wanita maka diyakini pula proses upacara tidak akan berlangsung secara sempurna. Dari uraian tersebut jelaslah Nampak bahwa kedudukan kaum wanita tersubordinasi dalam proses pendidikan politik di tingkat lingkungan desa pekraman yang menyebabkan kesadaran politik kaum wanita menjadi rendah dengan menggantungkan partisipasi politiknya pada kaum laki-laki saja.

\subsubsection{Proses Pendidikan Politik Perempuan Tigawasa Melalui Jalur Sekolah}

Wanita desa Tigawasa memperoleh kesempatan yang sama untuk mengenyam pendidikan formal di sekolah. Ini sangat 
memungkinkan karena sebagaian besar orang tua di desa Tigawasa telah sadar untuk menyekolahkan anak mereka sampai ke jengjang yang tinggi. Di dalam proses pendidikan politik yang berlangsung di sekolah dinilai lebih sistematis, lebih kompleks dan lebih utuh. Dikatakan demikian karena sekolah memiliki kurikulum pendidikan politik baik secara langsung melalui mata pelajaran yang diberikan di sekolah. Sekolah juga memberikan kegiatan yang membantu menumbuh kembangkan sikap berpolitik secara tidak langsung diberikan. Kegiatan kelompok belajar, organisasi siswa serta kegiatan lain yang diadakan di sekolah secara tidak langsung telah memberikan pengetahuan politik kepada para siswanya.

Dari uraian diatas jelas bahwa wanita Tigawasa telah memperoleh kesempatan yang sama dengan kaum laki-lakinya di dalam proses pendidikan kesadaran politik dalam lingkungan sekolah baik itu dari mata pelajaran yang diberikan maupun dari aktivitas sosial politik di lingkungan sekolah yang dapat meningkatkan wawasan dan partisipasinya di dalam politik.

\subsubsection{Partisipasi Perempuan Dalam Kehidupan Politik Di Desa Tigawasa}

Perempuan di desa Tigawasa sebagai warga desa adat dan warga masyarakat pada umumnya tidaklah jauh berbeda dengan wanita masyarakat lainya khususnya pada masyarakat Bali, khususnya yang nampak pada desa Tigawasa lebih mengacu pada keterikatan social budayanya, serta dan peran serta kaum wanitanya di dalam desa adat yang membedakan masyarakat Bali pada umumnya dilihat dari segi politik, wanita desa Tigawasa memiliki peranan yang sangat kuat khususnya dalam upacara keagamaan.

Dilihat dari segi pendidikan politik bagi kaum wanita di desa Tigawasa, tampaklah bahwa pendidikan tersebut lebih banyak berlangsung secara informal, artinya bahwa pendidikan politik bagi kaum wanita di desa Tigawasa lebih banyak berlangsung di dalam lingkungan keluarga dan lingkungan sehari-hari dan dimasyarakat. Hal ini dapat dibuktikan dari kenyataan bahwa sebagian besar kaum wanita yang pendidikannya hanya sampai di tingkat sekolah dasar. Dengan demikian proses pendidikan politik wanita di desa Tigawasa senantiasa berakar pada kebudayaan masyarakat di desa itu sendiri. Pendidikan politik di desa Tigawasa khususnya bagi kaum wanita senantiasa dihiasi dan dijiwai oleh nilai-nilai social budaya yang ada pada masyarakat itu sendiri. Pemahaman dan orientasi politik mereka terbentuk dan terlatih secara alamiah dalam dimensi kehidupan keluaraga dan masyarakat.

Banyak hal yang perlu ditingkatkan untuk menunjang keterlibatan kaum wanita di desa Tigawasa dalam segi pembangunana non fisik pemerdayaan tentang pola kehidupan sehari-hari dimana wanita sebagai benteng dalam meningkatkan perekonomian rakyat di desa Tigawasa. Disisi lain juga berkembang organisasi lainya seperti : organisasi PKK adalah dimana organisasi ini merupakan wadah bentuk dari aspirasi wanita di desa Tigawasa. Kaum wanita di desa Tigawasa juga menginginkan terwujudnya kesetaraan gender dengan laki-laki di segala aspek kehidupan khususnya di pemerintahan. Mereka menginginkan adanya perlakuan dan peran yang sama dalam menentukan kehidupan politik khususnya di desa baik yang menyangkut perencanaan pelaksanaan dan menikmati hasil dari kebijakan itu sendiri

\subsubsection{Keberterimaan Kaum Laki-Laki Terhadap Partisipasi Perempuan Di Dalam Kehidupan Politik Di Desa Tigawasa}

Pada dasarnya manusia diciptakan adalah dalam kondisi yang sama antara yang satu dengan yang lain, namun seiring dengan perkembangan statusnya maka terjadi pembeda yang sangat kental dan trasparan yang membedakan antara kaum laki-laki dengan kaum wanita. Perbedaan ini terjadi di berbagai aspek di dalam masyarakat. Kaum wanita cendrung dianggap lebih lemah dibandingkan dengan kaum laki-laki.

Di desa Tigawasa perbedaanperbedaan tersebut masih merupakan sesuatu yang biasa dan wajar, oleh karena itu banyak ditemukan ketidak adilan yang dialami masyarakat. Namun seiring dengan 
perkembangan zaman, maka dapat terlihat perbedaan yang terjadi sesudah semakin menipis. Kenyataan yang terjadi di lapangan menunjukan bahwa wanita di desa Tigawasa mempunyai andil yang sangat penting bagi kelancaran khususnya dalam rumah tangga. Pekerjaan yang biasanya dilakukan oleh laki-laki juga bisa dilakukan oleh para wanitanya meskipun pekerjaan tersebut terlihat sulit bagi sebagian orang. Selain mengerjakan pekerjaan rumah sehari-hari, wanita Tigawasa juga ada yang membuat kerajinan sokasi dan bedeg (Anyaman bambu), ada pula yang menjadi pedagang dan lain sebagainya. Hal tersebut dilakukan untuk membantu menunjang keadaan ekonomi keluarga seperti kebutuhan rumah tangga, biaya sekolah anak dan lain sebagainya.

\subsection{Pembahasan}

Perempuan desa Tigawasa sebagai warga negara desa adat dan warga masyarakat, pada umumnya, secara humanitis tidak jauh berbedadengan wanita pada masyarakat lainnya. Khususnya yang nampak pada wanita desa Tigawasa lebih mengacu pada keterikatan sosial budaya dan peranannya di dalam desa adat itu sendiri. Dilihat dari segi politik wamita Tigawasa memiliki eksistensi yang sangat kuat khususnya di dalam upacara keagamaan. Mereka memiliki peranan yang penting dalam kegiatan adat istiadat keagamaan di desa adat. Hal ini tidak terlepas dari situs sosial budaya masyarakat desa Tigawasa yang memiliki aturan tersendiri.

Dilihat dari segi pendidikan politik bagi kaum perempuan di Tigawasa tampak bahwa pendidikan politik tersebut berlangsung secara tidak langsung. Artinya bahwa pendidikan politik bagi kaum wanita di desa Tigawasa lebih banyak berlangsung di dalam lingkungan dan kehidupan seharihari dalam masyarakat. Kenyataan yang ditemui dilapangan menunjukan bahwa sebagian besar kaum perempuan di desa Tigawasa yang tingkat pendidikannya hanya pada tingkat sekolah SMP saja. Oleh karena itu proses pendidikan wanita di desa Tigawasa berakar pada kebudayaan masyarakat di desa itu sendiri. Pemahaman dan orintasi politik mereka terbentuk secara alami dalam dimensi kehidupan keluarga dan masyarakat. Pendidikan politik kaum wanita di desa Tigawasa senantiasa dihiasi dan dijiwai oleh nilai-nilai sosial budaya yang ada pada masyarakat itu sendiri. Pemahaman dan orientasi politik mereka terbentuk dan terlatih secara alamiah dalam dimensi kehidupan keluarga dan masyarakat.

Berdasarkan wawancara yang dilakukan dengan tokoh masyarakat setempat, bahwa pada pemilu tahun 2014 terdapat satu orang wanita Tigawasa mencalonkan diri sebagai wakil di daerah, organisasi wanita juga eksis dan mendapat dukungan yang positif dari masyarakat. Keterlibatan wanita sangatlah penting sekali untuk menyelaraskan dan menyetarakan hak kaum perempuan dalam hal melaksanakan aspek kehidupan bermasyarakat dan bernegara karena keterlibatan kaum wanita adat. $\mathrm{Hal}$ ini cukup membuktikan potensi kaum wanita dalam hal kesetaraan di berbagai aspek kehidupan.

Untuk menumbuhkan tingkat kesadaran politik kaum wanita Tigawasa dalam hal memperoleh kesempatan untuk memperoleh pendidikan menurut sekretaris desa yaitu Bapak I Ketut Cinta yaitu yaitu dengan secara memfasilitasi dan mendukung segala kegiatan-kegiatan organisasi wanita di desa Tigawasa baik itusecara administrasi maupun keuangan, sedangkan dalam hal pendidikan pemerintah desa memberikan kesempatan kepada semua warganya untuk bias memperoleh pendidikan dengan menyelenggarakan program-program yang telah dilakukan oleh pemerintah. Programprogram ini seperti kejar paket A dan C, sekolah satu atap, dan kegiatan lain yang berhubungan dengan pengembangan potensi pendidikan.

Dilihat dari segi ekonomi, wanita di desa Tigawasa memiliki eksistensi yang tinggi dan orientasi yang kokoh terkait dengan kehidupan ekonomi khususnya keluarga terkait dengan terwujudnya kesetaraan fungsi dan perandalam kehidupan di masyarakat.Wanita di desa Tigawasa menunjukan kemandirian dan keterbukaan dalam kehidupannya. Mereka 
telah mampu mengambil sikap dan keputusan yang berkaitan dengan masa depan dan kehidupannya. Wanita Tigawasa adalah wanita terbuka yang mampu menerima akultrasi dan budaya luar. Wanita Tigawasa juga bisa menentukan pasangannya sendiri, termasuk ketika mereka akan melangsungkan pernikahan.

Dalam konteks demokrasi walaupun biasanya peranan laki-laki memiliki hal lebih di bandingkan dengan kaum wanita namun pada kenyataannya pihak perempuan diberikan hak yang sama dan dihormati dalam pengambilan keputusan. Oleh karena itu demokrasi merupakanse suatu yang telah tumbuh dan berkembang dengan subur di lingkungan keluarga di masyarakat desa Tigawasa. Wanita di desa Tigawasa sangat paham dengan pekembangan dan situasi masyarakat pada saat ini, hal tersebut dapat dibuktikan dari pendapat dan pandangan kaum wanita terhadap segala peristiwa yang terjadi di berbagai daerah yang mereka simak melalui televisi maupun radio.

Pemerintah telah memberikan kesempatan kepada kaum wanita untuk dapat duduk secara langsung sebagai wakil baik itu di pemerintah pusat ataupun daerah. Dengan kuota 30\% posisi yang diberikan untuk kaum wanita, diharapkan maupun meningkatkan kualitas politik kaum wanita terutama dalam pengambil keputusan, menikmati hak-haknya seperti yang tertuang dan dijamin dalam konstitusi dan undang-undang atau peraturan lainnya. Dengan dikeluarkannya peraturan tersebut, maka telah memberikan peluang bagi kaum perempuan desa Tigawasa untuk terjun ke partai politik dan dengan harapan untuk mewujudkan kesetaraan dan peran ganda wanita bias tercapai. Banyak hal yang perlu ditingkatkan dalam hal keterlibatan kaum wanita di desa Tigawasa di dalam pembangunan non fisik, pemerdayaan polapola kehidupan sehari-hari, dimana perempuan sebagai benteng dalam hal perekonomian masyarakat dan yang menjadi sasaran atau program di desa Tigawasa dengan berupaya menumbuhkembangkan perekonomian di desa Tigawasa dengan cara membuat kelompok-kelompok untuk memajukan kaum perempuan di desa Tigawasa.
Kegiatan-kegiatan kerajinan yang ditekuni oleh sebagian besar masyarakat desa Tigawasa perlu mendapat perhatian khusus karena selama ini potensi kerajinan ini sangat berpotensi dalam membantu ekonomi keluarga di desa Tigawasa.

\section{PENUTUP}

Dari hasil penelitian yang telah dilakukan maka dapatlah disimpulkan halhal sebagai berikut: (1) Bahwa proses pendidikan politik di desa Tigawasa relatif sudah berjalan dengan sangat baik. Proses pendidikan politik ini, berjalan melalui proses pendidikan formal yang diakui oleh masyarakat, khususnya para perempuan di desa Tigawasa. Kesadaran para orang tua untuk menyekolahkan anak-anaknya, termasuk anak perempuan sudah relatif tinggi. Hal ini ditunjukan dengan terus meningkatnya tingkat pendidikan politik di masyarakat, proses pendidikan perempuan di desa Tigawasa di awali dari pendidikan di sekolah, keluarga, masyarakat dan di desa adat. (2) Bahwa partisipasi perempuan di desa Tigawasa sebelum adanya pendidikan politik relatif rendah, yaitu partisipasinya berkisar $30 \%$. Setelah melalui pendidkan politik baik lewat pendidikan formal maupun informal, partisipasi perempuan di Tigawasa dalam kehidupan politik meningkat menjadi 75\%. (3) Kaum laki-laki di desa Tigawasa sudah mengakui hak-hak kaum perempuan dalam partisipasinya di kegiatan politik seperti memberikan suara dalam pemilihan umum, menjadi anggota suatu partai politik atau kelompok kepentingan, mengadakan hubungan (contracting) dengan pejabat pemerintah atau anggota parlemen, dan mendukung bila nantinya akan ada perempuan yang menjadi pemimpin yang bisa membawa desa Tigawasa kearah yang lebih maju.

Berdasarkan simpulan penelitian sebagaimana yang telah di sampaikan di atas, maka berkaitan dengan temuan dari penelitian ini dapat ditarik suatu saran sebagai berikut: (1) Pendidikan politik di desa Tigawasa masih sangat perlu di tingkatkan dengan memberikan kesempatan melalui kegiatan-kegiatan yang bersifat khusus untuk kaum perempuan. (2) Hendaknya peranan pemerintah sangat diharapkan di dalam pelaksanaan kegiatan- 
kegiatan tersebut khususnya yang bersifat financial karena sebagian besar warga Tigawasa berada dalam keadaan ekonomi yang kurang. (3) Masyarakat hendaknya menyadari tentang arti pentingnya pendidikan politik sehingga kehidupan bermasyarakat berjalan lebih dinamis dan kesenjangan sosial yang terjadi di masyarakat sedikit demi sedikit dapat dikurangi bahkan dihilangkan.

\section{DAFTAR RUJUKAN}

Budiardjo, Miriam. 1981. Partisipasi dan Partai Politik. Jakarta: PT Gramedia

Kaur ,Amrit.2002. Kaum Perempuan dan Ketidakadilan Sosial.

Yogyakarta:Mahatma Gandhi.

Noviari Kusuma, Ni Made. 2010. Model Pendidikan Politik Berbasis Desa Adat Bagi Kaum Wanita Di Desa Tigawasa Kabupaten Buleleng Propinsi Bali. Skripsi. Universitas Pendidikan Ganesha.

Kertih, Drs. I Wayan M.pd dan Lasmawan,Prof. Dr. 2003. Pendidikan Politik \% IKIP Negeri

Nazarudin. 1990. Kaliodoskop Politik Indonesia. Jakarta : Graffiti Press

Netra. 1974. Metodelogi Penelitian Singaraja. Denpasar Biro Penelitian Fakultas IImu Pendidikan Universitas Udayana.

Undang-Undang Negara Republik Indonesia Nomor 2 Tahun 2008 tentang Partai Politik.

Undang-Undang Negara Republik Indonesia Nomor. 31 Tahun 2002 tentang partai politik,

Undang-Undang Negara Republik Indonesia Nomor. 12 Tahun 2003 tentang pemilu. 